\title{
Strategies to Reduce Inorganic Fertilizer Inputs in Crop Production through Integrated Crop-livestock Systems
}

\author{
Akim Omokanye ${ }^{1,2}$, Yamily Zavala ${ }^{3}$, Dianne Westerlund ${ }^{3}$, Liisa Jeffrey ${ }^{1}$ \& Buthaina Al-Maqtari ${ }^{1}$ \\ ${ }^{1}$ Peace Country Beef \& Forage Association, Room 229 TIB, Grande Prairie Regional College, Fairview Campus, \\ Box 3000, Fairview Alberta, T0H 1L0, Canada \\ ${ }^{2}$ Department of Renewable Resources, Faculty of Agricultural, Life \& Environmental Sciences, University of \\ Alberta, 2-06 Agriculture Forestry Centre, Edmonton, AB T6G 2P5, Canada \\ ${ }^{3}$ Chinook Applied Research Association, Highway 41 E, Box 690 Oyen, Alberta T0J 2J0, Canada \\ Correspondence: Akim Omokanye, Peace Country Beef \& Forage Association, Room 229 TIB, Grande Prairie \\ Regional College, Fairview Campus, Box 3000, Fairview Alberta, T0H 1L0, Canada. E-mail: akim@pcbfa.ca; \\ aomokanye@gmail.com
}

\author{
Received: November 24, 2021 Accepted: January 10, $2022 \quad$ Online Published: January 26, 2022 \\ doi:10.5539/sar.v11n1p45 \\ URL: https://doi.org/10.5539/sar.v11n1p45
}

\begin{abstract}
Adequate nutrition is essential for crop growth, production, and profit potential for farmers, but chemical fertilizer costs alone can constitute a greater portion of the total variable costs for wheat and canola. The present study evaluated seven cropping treatments (CT) in a 3-year crop rotation under two different soil types. Five of the CTs consisted of a one-time application (year 1) of beef cattle manure, and growing of cover crop cocktails (CCC) for annual pasture, swath grazing, green manure, and green feed. Canola and wheat were respectively grown in years 2 and 3 of the 3-year crop rotation. In year 2, CTs impacted canola seed yield and seed protein (only at site 2). Wheat had similar protein content in year 3 at both sites. At both sites, the application of beef cattle manure in year 1 seemed to encourage higher plant tissue $\mathrm{P}$ at the expense of plant tissue Zn. Overall, beef cattle manure and CCCs based CTs improved soil N, P, and K, but beef cattle manure application consistently improved crop yield and significantly reduced the need for additional in-organic fertilizer application to canola and wheat in subsequent years.
\end{abstract}

Keywords: cover cropping, wheat, canola, integrated crop-livestock production, soil nutrients

\section{Introduction}

The study of the environmental impacts of crops, the reduced costs of production, and the balanced use of fertilization are among the main objectives of modern agriculture (Yousaf et al., 2016). In Alberta, Canada, a recent AgriProfit\$ report showed that chemical fertilizer costs could constitute up to $30 \%$ of the total variable costs for wheat and 33\% for canola (AAF, 2021) indicating that in-organic fertilizer alone could have the highest of any single input cost in wheat and canola production. Concomitant with this is that over the last four years, the costs of fertilizers have escalated by as much as $40 \%$ for urea, $37 \%$ for mono-ammonium phosphate, $22 \%$ for muriate of potash, and $9 \%$ for ammonium sulphate. The high fertilizer costs and the unstable prices of beef cattle and grains are causing producers to look for different ways to manage farming systems that will improve soil fertility and health, and reduce in-organic fertilizer application without sacrificing crop yields.

A preliminary study that examined the soil nutrient status after forage harvests of cover crop monocultures and a CCC in northern Alberta showed the potential of cover crops and their mixtures to improve soil fertility for subsequent crop production (Omokanye, 2019). Similarly, in eastern Alberta, initial evaluations of CCCs showed the potential of CCCs to provide a reduction in soil compaction, increased weed suppression and aggregation formation for the next cropping season, as well as improved biological activity (CARA, 2016), all of which will have positive impacts on crop production and overall farm profits. This further shows the need for a multifunctional low-input cropping system that includes CCCs. The benefits of CCCs are based on the multifunctional action of each crop species in the blend interacting with the soil attributes and stimulating the soil's biological activity (Barot et al., 2017).

Garrett et al. (2017) indicated that farmers' motivations for re-integrating animals into cropland are varied, but 
often include risk reduction through diversification, increased nutrient and land-use efficiency, and climate resilience through enhanced adaptability of management options. Yet, crop production outcomes following livestock grazing across environments and management scenarios remain uncertain and are a potential barrier to adoption, as producers worry about the effects of livestock activity on the agronomic quality of their land. Integrated crop-livestock systems investigated using a meta-analysis on three soil types reported 5\% higher yields than unintegrated systems for one soil type, and no difference between integrated and unintegrated systems on the other soils (Peterson et al., 2020). Crop nutrient uptake and crop yields are the principal factors that determine optimal fertilization practices (Ju and Christie, 2011), hence the need to apply fertilizers in an efficient way to minimize loss and to improve the nutrient use efficiency (Li et al., 2009). There is, therefore, the need for more integrated forms of agriculture to restore the sustainability of agricultural systems (Bell and Moore, 2012; Hendrickson et al., 2008; Russelle et al., 2007). Crop-livestock integration pursues three aims: reducing the openness of nutrient cycles, following the rationale of industrial ecology, organizing land use and farming practices to promote ecosystem services, and increasing farm resilience to adverse climatic and economic events (Bonaudo et al., 2014; Lemaire et al., 2014; Moraine et al., 2014).

In this study, 3-year field-scale experiments were conducted at two sites with different soil types to study the effectiveness of different cropping systems, including CCCs, livestock integration, and the use of manure and bio-stimulants on subsequent canola and wheat crop production and the impact on soil characteristics.

\section{Materials and Methods}

\subsection{Experimental Site Description}

Field experiments were conducted from 2018-2020 at two sites in Alberta, Canada. Site 1 was at Fairview Research Farm (Fairview) and site 2 was at Sedalia. The soil group at Fairview is dark gray chernozemics and brown chernozemics at Sedalia (AGRASID; GOA 2020). At the start of the project, the Fairview site had a soil $\mathrm{pH}$ of 5.19 (0-6"), 5.55 (6-12") and 5.81 (12-18"), and a soil organic matter (SOM) content of 6.99\% (0-6"), 3.06\% (6-12") and 2.32\% (12-18”). The soil at Sedalia had a soil pH of 5.67 (0-6"), 6.59 (6-12"), and 6.80 (12-18"), while the SOM was $2.71 \%, 3.06 \%$, and $2.32 \%$, respectively from $0-6 ", 6-12$ " and $12-18$ ". Both sites have a subarctic climate (also called boreal climate), which is characterized by long, usually very cold winters, and short, cool to mild summers. Fairview site was seeded to oats for greenfeed two years before the commencement of the experiment but left fallow the year before the experiment started. During the fallow period (uncultivated), the plants growing in the field were mowed down a few times during growing season. Sedalia had canola seeded the year before and combined harvested. Growing season precipitation, air temperatures, and growing degree days during the study and long-term averages for both sites acquired through the Alberta Climate Information System (ACIS, 2020) weather station are shown in Table 1.

Table 1. Monthly mean air temperature $\left({ }^{\circ} \mathrm{C}\right)$, precipitation $(\mathrm{mm})$, and growing degree days for the 3 growing seasons (2018, 2019 and 2020), and their long-term averages (LTA) at both sites

\begin{tabular}{|c|c|c|c|c|c|c|c|c|}
\hline & \multicolumn{4}{|c|}{ Site 1: Fairview (Northwestern Alberta) } & \multicolumn{4}{|c|}{ Site 2: Sedalia (Eastern Alberta) } \\
\hline & 2018 & 2019 & 2020 & LTA & 2018 & 2019 & 2020 & LTA \\
\hline \multicolumn{9}{|c|}{ Rainfall (mm): } \\
\hline May & 5.3 & 7.4 & 35.3 & 38.7 & 15 & 2.7 & 50.9 & 35.5 \\
\hline June & 77.3 & 72.9 & 67.2 & 103 & 62.1 & 53.2 & 96.3 & 73.1 \\
\hline July & 108.5 & 61.9 & 89.8 & 69.5 & 48.2 & 107 & 93.9 & 55.6 \\
\hline August & 23.3 & 49.1 & 53.9 & 47.5 & 17.8 & 13.6 & 17.4 & 40.4 \\
\hline September & 32.9 & 24.6 & 23.1 & 81.2 & 25.4 & 44.3 & 26.3 & 29.8 \\
\hline Total & 247.3 & 215.9 & 269.3 & 339.9 & 168.5 & 220.8 & 284.8 & 234.4 \\
\hline \multicolumn{9}{|c|}{ Air temperatures $\left({ }^{\circ} \mathrm{C}\right)$ : } \\
\hline May & 14.3 & 11.5 & 9.9 & 9.9 & 14.5 & 10.1 & 10.4 & 10.7 \\
\hline June & 14.9 & 14.1 & 14 & 14 & 16.5 & 15 & 15.1 & 15.1 \\
\hline July & 16.3 & 15.1 & 15.6 & 15.8 & 18.2 & 17.1 & 17.4 & 17.9 \\
\hline August & 14.7 & 12.9 & 14.1 & 14.6 & 17.4 & 15.8 & 17.7 & 17.1 \\
\hline September & 4.41 & 9.68 & 10.3 & 9.57 & 7.29 & 11.3 & 12.3 & 11.3 \\
\hline \multicolumn{9}{|c|}{ Growing degree days $\left(5^{\circ} \mathrm{C}\right)$ : } \\
\hline May & 272 & 210 & 158 & 161 & 183 & 152 & 161 & 183 \\
\hline June & 297 & 273 & 272 & 269 & 304 & 292 & 292.3 & 304 \\
\hline July & 344 & 306 & 330 & 334 & 399 & 382 & 380.3 & 399 \\
\hline August & 293 & 248 & 283 & 298 & 375 & 331 & 394.2 & 375 \\
\hline September & 39 & 162 & 157 & 147 & 106 & 209 & 221.5 & 196 \\
\hline Total & 1245 & 1199 & 1200 & 1209 & 1367 & 1366 & 1449.3 & 1457 \\
\hline
\end{tabular}




\subsection{Treatments and Experimental Design}

This experiment was designed to examine the effect of a one-time application of seven CTs on soil fertility, and canola and wheat production over a 3-year period at both sites. The CTs were examined (Table 2) using a randomized complete block design with three replications.

Table 2. The seven cropping treatments (CT) investigated from 2018 to 2020

\begin{tabular}{|c|c|c|c|}
\hline Brief description of CT & 2018 & 2019 & 2020 \\
\hline $\begin{array}{l}\text { Conventional rotation (control). } \\
\text { P-C-W (control) }\end{array}$ & CDC Meadow peas $(\mathrm{P})$ & Canola (C) & $\begin{array}{l}\text { Wheat } \\
\text { (W) }\end{array}$ \\
\hline $\begin{array}{l}\mathrm{CCC}_{\mathrm{G}} \text { (grazed as a standing } \\
\text { crop) - canola - wheat rotation. } \\
\mathrm{CCC}_{\mathrm{G}}-\mathrm{C}-\mathrm{W}\end{array}$ & $\begin{array}{l}\text { CCC mixture seeded. } \\
\text { Fairview (used } 6 \text { cow-calf pairs to graze CCC) in fall. } \\
\text { Sedalia (grazed by } 5 \text { dry cows) in fall. }\end{array}$ & $\begin{array}{l}\text { Canola } \\
\text { (C) }\end{array}$ & $\begin{array}{l}\text { Wheat } \\
\text { (W) }\end{array}$ \\
\hline $\begin{array}{l}\mathrm{CCC}_{\mathrm{SG}} \text { (swathed and grazed) } \\
\text { - canola - wheat rotation. } \\
\mathrm{CCC}_{\mathrm{SG}}-\mathrm{C}-\mathrm{W}\end{array}$ & $\begin{array}{l}\text { CCC mixture seeded. } \\
\text { CCC swathed when oats were at the soft dough stage. } \\
\text { Fairview (grazed by } 6 \text { cow-calf pairs) in fall. } \\
\text { Sedalia (grazed by } 5 \text { dry cows) in fall. }\end{array}$ & $\begin{array}{l}\text { Canola } \\
\text { (C) }\end{array}$ & $\begin{array}{l}\text { Wheat } \\
\text { (W) }\end{array}$ \\
\hline $\begin{array}{l}\text { Barley (manure) - canola } \\
\text { - wheat rotation. } \\
\mathrm{B}_{\mathrm{M}-\mathrm{C}-\mathrm{W}}\end{array}$ & $\begin{array}{l}\text { Stockpiled beef cattle manure was applied and } \\
\text { harrowed into the soil before seeding. } \\
\text { CDC Maverick barley was seeded. } \\
\text { No additional chemical fertilizer was applied. }\end{array}$ & $\begin{array}{l}\text { Canola } \\
\text { (C) }\end{array}$ & $\begin{array}{l}\text { Wheat } \\
\text { (W) }\end{array}$ \\
\hline $\begin{array}{l}\mathrm{CCC}_{\mathrm{R}} \text { (rolled as green manure) } \\
\text { - canola - wheat rotation. } \\
\mathrm{CCC}_{\mathrm{R}}-\mathrm{C}-\mathrm{W}\end{array}$ & $\begin{array}{l}\text { CCC mixture seeded. } \\
\text { CCC was rolled onto the surface soil as green manure } \\
\text { when the oats were at the late milk-soft dough stage. }\end{array}$ & $\begin{array}{l}\text { Canola } \\
\text { (C) }\end{array}$ & $\begin{array}{l}\text { Wheat } \\
\text { (W) }\end{array}$ \\
\hline $\begin{array}{l}\text { High legume-base } \mathrm{CCC}_{\mathrm{F}}(40 \% \text { cereals } \& \\
60 \% \text { legumes for greenfeed }) \text { - canola - } \\
\text { wheat rotation. } \\
\mathrm{CCC}_{\mathrm{F}}-\mathrm{C}-\mathrm{W}\end{array}$ & $\begin{array}{l}\text { CCC mixture seeded. } \\
\text { Harvested for forage and removed from the } \\
\text { field when the oats were at the late milk stage. }\end{array}$ & $\begin{array}{l}\text { Canola } \\
\text { (C) }\end{array}$ & $\begin{array}{l}\text { Wheat } \\
\text { (W) }\end{array}$ \\
\hline $\begin{array}{l}\text { Barley - canola - wheat rotation } \\
\text { (Bio-stimulants applied yearly). } \\
B_{P}-C_{P}-W_{P}\end{array}$ & $\begin{array}{l}\text { CDC Maverick barley seeded. } \\
\text { Penergetic K applied at seeding. } \\
\text { Penergetic P applied as in-crop (foliar) application. }\end{array}$ & $\begin{array}{l}\text { Canola } \\
(\mathrm{C}) \\
+ \text { PKP }\end{array}$ & $\begin{array}{l}\text { Wheat } \\
(\mathrm{W}) \\
+ \text { PKP }\end{array}$ \\
\hline
\end{tabular}

Note.

Water and free choice trace mineralized stock salt were provided to the cows during grazing in 2018.

$\mathrm{CCC}_{\mathrm{G}}$ and $\mathrm{CCC}_{\mathrm{R}}$ consisted of oats, German millet, annual ryegrass, hairy vetch crimson clover, Winfred forage brassica, and sunflower.

$\mathrm{CCC}_{\mathrm{SG}}$ was made up of oat, Italian ryegrass, frosty berseem clover, peas, and Winfred forage brassica.

$\mathrm{CCC}_{\mathrm{F}}$ consisted of oats, peas, crimson clover, and hairy vetch.

For all CCCs, a substitutive approach (proportional replacement design) was used for calculating seeding rates (Omokanye et al., 2019).

No chemical fertilizer was applied to the CCCs and barley + manure $\left(\mathrm{B}_{\mathrm{M}}\right)$ in 2018.

Except for $\mathrm{B}_{\mathrm{M}} \mathrm{C}-\mathrm{W}$, crops were fertilized with inorganic fertilizers from 2018 to 2020 .

Fairview (canola in 2018 and wheat in 2020) received half of the recommended in-organic fertilizer rates following soil test reports. Sedalia had a uniform in-organic fertilizer rate applied to all crops every year. In-organic fertilizer applications were at seeding.

At site 1, seeding dates were May 28 (2018), May 22 (2019), and May 21 (2020). Site 2 was seeded on May 25 (2018), May 27 (2019), and May 31 (2020). Plot size was about 1,102 $\mathrm{m}^{2}$ with an alleyway of $1 \mathrm{~m}$ between plots. In 2019, a canola hybrid with Pioneer® Protector Harvest-Max CR traits (45CM39) was seeded. Canada Western Red Spring wheat (AAC Brandon wheat) was seeded in 2020. All crop monocultures from 2018 to 2020 were seeded using the desired plant population per ha (AAF, 2018). For combine harvesting, all monocultures were harvested for grain after they had reached physiological maturity stages.

\subsection{Soil Measurements}

Every year, prior to seeding, soil characteristics were measured. The soil physical properties measured were bulk density [BD: 0-15 cm soil depth, expressed as mass per unit volume of soil $\left(\mathrm{g} / \mathrm{cm}^{3}\right)$ ] and water-stable aggregates. Soil samples for water-stable aggregates and biological activities $(0-7.5 \mathrm{~cm}$ and $7.5-15 \mathrm{~cm}$ soil depths), which included microbial activity $\left(\mathrm{CO}_{2}\right.$ respiration) and active carbon (AC) were analyzed at the Chinook Applied Research Association's Soil Health Laboratory using the University of Cornell Soil Health protocols (Schindelbeck et al., 2016). Total carbon (TC), total organic carbon (TOC), and total nitrogen (TN) were analyzed at the University of Alberta Natural Resources Analytical Laboratory by combustion elemental analysis (Sparks et al., 2020; Schumacher, 2002). Soil samples were transported in a cooler and stored in a fridge before analysis. Calculation of the amount of soil C density or soil organic carbon (SOC) stock (carbon tha ${ }^{-1}$ ) to $30-\mathrm{cm}$ depth in soil was calculated using SOC concentration (\%) and bulk density $\left(\mathrm{g} \mathrm{cm}^{-3}\right)$ as per GOWA (2021). 
Soil samples for soil chemical properties (at $0-15 \mathrm{~cm}$ soil depth) including nitrate- $\mathrm{N}, \mathrm{P}, \mathrm{K}$, and $\mathrm{S}$, and soil $\mathrm{pH}$ and organic matter were shipped to A\&L Canada Laboratories Inc., London, Ontario for analysis. Using KCl extraction with the cadmium-reduction, nitrate- $\mathrm{N}$ concentration was quantified colorimetrically (Maynard et al., 2008) by an auto-analyzer (Technicon Auto-Analyzer II, Tarrytown, NY). A Mehlich III (Mehlich 1984) extraction was used for $\mathrm{S}$ and determination of $\mathrm{S}$ was by inductively-coupled plasma atomic emission spectrometry (ICP-OES). Concentration data for $\mathrm{N}, \mathrm{P}, \mathrm{K}$, and $\mathrm{S}$ were converted to content $\left(\mathrm{kg} \mathrm{ha}^{-1}\right)$.

\subsection{Plant Measurements}

For plant tissue analysis, canola and wheat plant tissue sampling was carried out as per the tissue sampling reference guide provided by A\&L Analytical Experts (A\&L Canada Lab., 2019). The growth stage for canola was pre-flower to $50 \%$ flower with the most recently matured leaf (5th from the top) sampled. Wheat was harvested at the bloom stage and most recently matured leaf sampled. Plant samples were sent to A \& L Canada Laboratory for plant tissue analysis. The oven-dried samples were ground into a powder form and passed through a $1 \mathrm{~mm}$ sieve. The leaf nitrogen content (expressed as a percentage) was then measured using the Laboratory Equipment Company (LECO) FP628 nitrogen/protein analyzer that uses the total nitrogen combustion method (AOAC, 2006).

Grain yield, grain crude protein (CP), and test weight were measured for canola (year 2) and wheat (year 3). Straw yields and quality were determined for the canola (2019) and wheat (2020). Straw samples were sent to A\&L Canada Laboratories for nutritive value.

\subsection{Data Analysis}

The data was analyzed on a site basis. As the experiment was designed to test the effect of a one-time application of seven CT treatments in year 1 (2018) on subsequent soil nutrients, soil biological activities, and crop grain and residue yields, the crop data in 2019 and 2020 was analyzed separately (on a yearly basis) using a pre-defined model procedure (1-way randomized block) from the CoStat - Statistics Software (version 6.2; CoStat 2005). Soil nutrients (N, P, K, and S) were analyzed using R statistical software (R-Studio, 2021) to determine the appropriate interactions, and CT and depth effects. Where ANOVA indicated significant effects, the means were separated by the least significant difference (LSD) at the 0.05 probability level. Significant differences in the text refer to $\mathrm{P}<0.05$.

\section{Results and Discussion}

\subsection{Canola and Wheat Grain Yields and Protein}

In year 2 of the rotation, canola yield differed significantly from prior CTs at both sites (Table 3). At both sites, $\mathrm{B}_{\mathrm{M}}-\mathrm{C}-\mathrm{W}$ produced the highest seed yield (site 1: $2632 \mathrm{~kg} \mathrm{ha}^{-1}$, site 2: $2464 \mathrm{~kg} \mathrm{ha}^{-1}$ ), followed by $B_{\mathrm{P}^{-}} \mathrm{C}_{\mathrm{P}^{-}}-\mathrm{W}_{\mathrm{P}}$ with 2296-2352 $\mathrm{kg} \mathrm{ha}^{-1}$ at both sites. At site 1 , only $\mathrm{B}_{\mathrm{M}^{-}} \mathrm{C}-\mathrm{W}$ and $\mathrm{B}_{\mathrm{P}}-\mathrm{C}_{\mathrm{P}}-\mathrm{W}_{\mathrm{P}}$ produced significantly higher seed yield than control (P-C-W), while at site $2, \mathrm{~B}_{\mathrm{P}}-\mathrm{C}_{\mathrm{P}^{-}}-\mathrm{W}_{\mathrm{P}}, \mathrm{B}_{\mathrm{M}^{-}} \mathrm{C}-\mathrm{W}$, and $\mathrm{CCC}_{\mathrm{R}}-\mathrm{C}-\mathrm{W}$ clearly showed significantly higher seed yield than control. At site $1, \mathrm{~B}_{\mathrm{P}}-\mathrm{C}_{\mathrm{P}^{-}}-\mathrm{W}_{\mathrm{P}}$ and $\mathrm{B}_{\mathrm{M}^{-}} \mathrm{C}-\mathrm{W}$ out-yielded other $\mathrm{CTs}$ by $280-1064 \mathrm{~kg} \mathrm{ha}^{-1}$ in canola seed yield, while at site 2 , the yield differences from both $\mathrm{B}_{\mathrm{P}}-\mathrm{C}_{\mathrm{P}}-\mathrm{W}_{\mathrm{P}}$ and $\mathrm{B}_{\mathrm{M}}-\mathrm{C}-\mathrm{W}$ over other CTs were 56-952 $\mathrm{kg} \mathrm{ha}^{-1}$. At site $1, \mathrm{CCC}_{\mathrm{F}}-\mathrm{C}-\mathrm{W}$ had the least canola seed yield. Unlike site 1 , where $\mathrm{CCC}_{\mathrm{G}}-\mathrm{C}-\mathrm{W}$ produced a similar canola yield to control, at site 2, both CTs that had CCC grazed the year before had lower canola seed yield than control. This shows that at both sites, the amounts of manure and urine from the CTs that involved grazing $\left(\mathrm{CCC}_{\mathrm{G}^{-}} \mathrm{C}-\mathrm{W}\right.$ and $\left.\mathrm{CCC}_{\mathrm{SG}^{-}} \mathrm{C}-\mathrm{W}\right)$ might not be substantial enough to provide any positive effect on the immediate subsequent crop. At site 2 , four of the $\mathrm{CTs}\left(\mathrm{B}_{\mathrm{M}}-\mathrm{C}-\mathrm{W}, \mathrm{CCC}_{\mathrm{R}}-\mathrm{C}-\mathrm{W}, \mathrm{B}_{\mathrm{P}}-\mathrm{C}_{\mathrm{P}^{-}}-\mathrm{W}_{\mathrm{P}}\right.$, and $\left.\mathrm{CCC}_{\mathrm{F}}-\mathrm{C}-\mathrm{W}\right)$ produced 504-784 $\mathrm{kg} \mathrm{ha}^{-1}$ canola seed yield than projected canola yield for the study area (AAF, 2019). At site 1 , only $\mathrm{B}_{\mathrm{M}^{-}} \mathrm{C}-\mathrm{W}$ and $\mathrm{B}_{\mathrm{P}}-\mathrm{C}_{\mathrm{P}}-\mathrm{W}_{\mathrm{P}}$ produced a higher canola seed yield than the projected canola yield for the area. With the reduction in inorganic fertilizer application to all CTs in year $2, \mathrm{~B}_{\mathrm{M}^{-}} \mathrm{C}-\mathrm{W}$ was still able to produce $448-784 \mathrm{~kg} \mathrm{ha}^{-1}$ canola seed yield between both sites.

Wheat grain yield in year 3 of the rotation was influenced significantly by $\mathrm{CT}$ at site 1 , but this was not the case at site 2 (Table 3). $\mathrm{B}_{\mathrm{M}^{-}} \mathrm{C}-\mathrm{W}$ produced the highest wheat grain yield $\left(5040 \mathrm{~kg} \mathrm{ha}^{-1}\right.$ ). $\mathrm{B}_{\mathrm{M}^{-}} \mathrm{C}-\mathrm{W}$ had had similar $(\mathrm{P}<0.05)$ grain yield to both $\mathrm{CCC}_{\mathrm{R}}-\mathrm{C}-\mathrm{W}$ and $\mathrm{B}_{\mathrm{P}}-\mathrm{C}_{\mathrm{P}^{-}}-\mathrm{W}_{\mathrm{P}}$, but differed significantly from other $\mathrm{CT}$. Other than $\mathrm{B}_{\mathrm{M}}-\mathrm{C}-\mathrm{W}$, both $\mathrm{CCC}_{\mathrm{R}}-\mathrm{C}-\mathrm{W}$ and $\mathrm{B}_{\mathrm{P}}-\mathrm{C}_{\mathrm{P}}-\mathrm{W}_{\mathrm{P}}$ had some form of similarity $(\mathrm{P}<0.05)$ in wheat grain yield to other $\mathrm{CT}$ investigated. At both sites (though treatments were not significantly different from each other at site 2), the control (P-C-W) seemed to consistently produce lower wheat grain value than other $\mathrm{CT}$. The wheat grain yield from both $\mathrm{B}_{\mathrm{M}^{-}} \mathrm{C}-\mathrm{W}$ and $\mathrm{CCC}_{\mathrm{R}}-\mathrm{C}-\mathrm{W}$ (though similar to control) at both sites in year 3 clearly indicates the carry-over of residual effects from year 1 from the spread of beef cattle manure and to some extent from CCC rolled as green manure $\left(\mathrm{CCC}_{\mathrm{G}}-\mathrm{C}-\mathrm{W}\right)$. At site 1 , even with the reduction in in-organic fertilizer application rates 
for the different CTs, all CT surprisingly produced more wheat grain yield than the projected yield estimate for the study area (AAF, 2020). $\mathrm{B}_{\mathrm{M}^{-}} \mathrm{C}-\mathrm{W}$, in particular, produced $\sim 1300 \mathrm{~kg} \mathrm{ha}^{-1}$ more yield than projected, followed by both $\mathrm{CCC}_{\mathrm{R}^{-}}-\mathrm{C}-\mathrm{W}$ and $\mathrm{CCC}_{\mathrm{R}}-\mathrm{C}-\mathrm{W}$, each with $\sim 875 \mathrm{ha}^{-1}$. At site 2 , only $\mathrm{B}_{\mathrm{P}}-\mathrm{C}_{\mathrm{P}^{-}}-\mathrm{W}_{\mathrm{P}}, \mathrm{B}_{\mathrm{M}^{-}}-\mathrm{C}-\mathrm{W}$, and $\mathrm{CCC}_{\mathrm{R}}-\mathrm{C}-\mathrm{W}$ seemed to produce some greater yield advantage than projected for the study area.

On a general note, in the present study, we used the continuous grazing method, where animals are allowed to have unrestricted, uninterrupted access to a specific unit of land throughout the entire grazing period of the treatment plots. This was thought to have accounted for the generally less impact (manure not evenly distributed) from both $\mathrm{CCC}_{\mathrm{G}}-\mathrm{C}-\mathrm{W}$ and $\mathrm{CCC}_{\mathrm{SG}^{-}} \mathrm{C}-\mathrm{W}$ on the immediate subsequent crop (canola) and even later for wheat in year 3 of the rotation. The greater impact from $\mathrm{CCC}_{\mathrm{G}}-\mathrm{C}-\mathrm{W}$ and $\mathrm{CCC}_{\mathrm{SG}}-\mathrm{C}-\mathrm{W}$ would have been found in this study had strip grazing been used for each grazed plot. Strip grazing technique involves utilizing a movable, electric fence to allot enough forage for a short time period and then moving the fence forward providing a new allocation of forage. Strip grazing can increase utilization, decrease animal selectivity and allow even distribution of manure and urine.

Canola seed crude protein (CP) was similar for all CTs at site 1, but differed significantly for CTs at site 2 (Table 3). At site $2, \mathrm{~B}_{\mathrm{P}}-\mathrm{C}_{\mathrm{P}}-\mathrm{W}_{\mathrm{P}}$ had significantly lower canola seed $\mathrm{CP}$ than other $\mathrm{CTs}$ (except for $\mathrm{B}_{\mathrm{M}}-\mathrm{C}-\mathrm{W}$ and $\left.C C C_{R}-C-W\right)$. Why canola seed $C P$ was lower for $B_{P}-C_{P}-W_{P}$ than most $C$ Ts at site 2 in this study is difficult to explain.

\subsection{Canola and Wheat Straw Yield and Nutritive Value}

At site 1 , the straw yield was influenced significantly by $\mathrm{CT}$, while at site 2 , canola straw was similar $(\mathrm{P}>0.05)$ for all CTs (Table 3). The highest straw yield came from $\mathrm{B}_{\mathrm{M}}-\mathrm{C}-\mathrm{W}$, followed by $\mathrm{B}_{\mathrm{P}}-\mathrm{C}_{\mathrm{P}}-\mathrm{W}_{\mathrm{P}}$ and then $\mathrm{P}-\mathrm{C}-\mathrm{W}$ at site 1 in that order. The highest straw yield from $\mathrm{B}_{\mathrm{M}}-\mathrm{C}-\mathrm{W}$ was probably a reflection of the higher seed yield produced by these CTs.

Both canola straw $\mathrm{CP}$ and energy in the form of total digestible nutrients (TDN) were not significantly affected by prior cropping management implemented in year 1 (2018) in this study at the two sites. The results of canola straw CP show that when integration of crop and livestock is involved and beef cattle are grazed on canola straw, the straw $\mathrm{CP}$ at both sites would be adequate and in most cases would be in excess of what a beef cow requires in early pregnancy according to NASEM recommendations (NASEM, 2016). At both sites 1 and 2, the straw TDN was short of meeting the TDN requirements of a beef cow in early pregnancy as recommended by NASEM (2016).

Wheat straw yield did not differ significantly for the CTs at both sites (Tables 3 and 4). Straw CP and TDN were significantly influenced by $\mathrm{CTs}$ at site 1 and greatly in favour of $\mathrm{B}_{\mathrm{P}}-\mathrm{C}_{\mathrm{P}}-\mathrm{W}_{\mathrm{P}}(8.46 \% \mathrm{CP}, 54.3 \% \mathrm{TDN})$ than other CTs. The straw $\mathrm{CP}$ at both sites $(5.43-9.33 \% \mathrm{CP})$ seemed to be sufficient in most cases for a beef cow in early to mid-pregnancy (NASEM, 2016). The straw TDN from both sites $(<55 \% \mathrm{TDN})$ on the other hand was generally below that suggested for a beef cow in early to mid-pregnancy (NASEM, 2016). 
Table 3. Seed/grain yield and CP (DM basis), and straw yield and straw CP and TDN (DM basis) for cropping treatments investigated in year 2 (2019, canola crop) and year 3 (2020, wheat crop) at both sites 1 and 2

\begin{tabular}{|c|c|c|c|c|c|c|c|c|c|c|}
\hline \multirow[b]{3}{*}{$\begin{array}{l}\text { Cropping } \\
\text { treatment }\end{array}$} & \multicolumn{10}{|c|}{ Canola } \\
\hline & \multicolumn{2}{|c|}{ Seed yield } & \multicolumn{2}{|c|}{ Seed CP } & \multicolumn{2}{|c|}{ Straw yield } & \multicolumn{2}{|c|}{ Straw CP } & \multicolumn{2}{|c|}{ Straw TDN } \\
\hline & $\begin{array}{l}\text { Site } 1 \\
\mathrm{Kg} \mathrm{ha}^{-1}\end{array}$ & Site 2 & $\begin{array}{l}\text { Site } 1 \\
\%\end{array}$ & Site 2 & $\begin{array}{l}\text { Site } 1 \\
\mathrm{Kg} \mathrm{ha}^{-1}\end{array}$ & Site 2 & $\begin{array}{l}\text { Site } 1 \\
\%\end{array}$ & Site 2 & $\begin{array}{l}\text { Site } 1 \\
\%\end{array}$ & Site 2 \\
\hline P-C-W & $2072 \mathrm{c}^{\mathbb{I I}}$ & $1736 \mathrm{bc}$ & 24.8 & $22.1 \mathrm{a}$ & $2442 b c$ & 2347 & 6.56 & 9.33 & 42.9 & 39.44 \\
\hline $\mathrm{B}_{\mathrm{P}}-\mathrm{C}_{\mathrm{P}}-\mathrm{W}_{\mathrm{P}}$ & $2352 b$ & $2296 a$ & 22.8 & $17.8 \mathrm{c}$ & $3445 \mathrm{ab}$ & 2709 & 6.26 & 6.64 & 41.9 & 36.92 \\
\hline $\mathrm{B}_{\mathrm{M}^{-}} \mathrm{C}-\mathrm{W}$ & $2632 a$ & $2464 a$ & 23.2 & $20.4 \mathrm{abc}$ & $3691 \mathrm{a}$ & 3312 & 7.17 & 7.17 & 44.2 & 36.97 \\
\hline $\mathrm{CCC}_{\mathrm{G}}-\mathrm{C}-\mathrm{W}$ & $2072 c$ & $1624 \mathrm{c}$ & 23.8 & $21.8 \mathrm{a}$ & $2377 \mathrm{c}$ & 2339 & 6.68 & 9.21 & 40.7 & 41.64 \\
\hline $\mathrm{CCC}_{\mathrm{F}}-\mathrm{C}-\mathrm{W}$ & $1568 \mathrm{~d}$ & $2184 \mathrm{abc}$ & 23.2 & $22.3 \mathrm{a}$ & $2191 \mathrm{c}$ & 2658 & 8.12 & 7.95 & 44.2 & 39.21 \\
\hline $\mathrm{CCC}_{\mathrm{R}}-\mathrm{C}-\mathrm{W}$ & NA & $2240 \mathrm{a}$ & NA & $18.8 \mathrm{bc}$ & NA & 3224 & NA & 8.12 & NA & 37.17 \\
\hline $\mathrm{CCC}_{\mathrm{SG}}-\mathrm{C}-\mathrm{W}$ & $1624 d$ & 1512 & 24.4 & $21.4 \mathrm{ab}$ & $2552 \mathrm{c}$ & 2321 & 7.31 & 7.82 & 42.7 & 38.26 \\
\hline \multirow[t]{3}{*}{$\mathrm{CV}^{\S}, \%$} & 4.50 & 13.7 & 5.74 & 8.04 & 24.2 & 19 & 15.6 & 11.3 & 6.55 & 6.23 \\
\hline & \multicolumn{10}{|c|}{ Wheat } \\
\hline & \multicolumn{2}{|c|}{ Grain yield } & \multicolumn{2}{|c|}{ Grain CP } & \multicolumn{2}{|c|}{ Straw yield } & \multicolumn{2}{|c|}{ Straw CP } & \multicolumn{2}{|c|}{ Straw TDN } \\
\hline Cropping & Site 1 & Site 2 & Site 1 & Site 2 & Site 1 & Site 2 & Site 1 & Site 2 & Site 1 & Site 2 \\
\hline treatment & \multicolumn{2}{|c|}{$\mathrm{Kg} \mathrm{ha}^{-1}$} & \multicolumn{2}{|c|}{$\%$} & \multicolumn{2}{|c|}{$\mathrm{Kg} \mathrm{ha}^{-1}$} & \multicolumn{2}{|c|}{$\%$} & \multicolumn{2}{|c|}{$\%$} \\
\hline P-C-W & $4032 \mathrm{bc}$ & 2352 & 18.7 & 12.83 & 2597 & 1415 & $7.07 \mathrm{c}$ & 9.33 & $50.9 \mathrm{c}$ & 39.4 \\
\hline $\mathrm{B}_{\mathrm{P}}-\mathrm{C}_{\mathrm{P}}-\mathrm{W}_{\mathrm{P}}$ & $4166 b c$ & 2890 & 18.2 & 9.86 & 2163 & 1340 & $8.46 \mathrm{a}$ & 6.63 & $54.3 \mathrm{a}$ & 36.9 \\
\hline $\mathrm{B}_{\mathrm{M}}-\mathrm{C}-\mathrm{W}$ & $5040 \mathrm{a}$ & 3091 & 18.3 & 11.23 & 2897 & 1431 & $6.73 d$ & 7.17 & $51.5 \mathrm{c}$ & 36.9 \\
\hline $\mathrm{CCC}_{\mathrm{G}}-\mathrm{C}-\mathrm{W}$ & 4634ab & 2486 & 19 & 10.55 & 2178 & 1184 & $5.43 \mathrm{~g}$ & 9.2 & $45.0 \mathrm{e}$ & 41.6 \\
\hline $\mathrm{CCC}_{\mathrm{F}}-\mathrm{C}-\mathrm{W}$ & $3629 \mathrm{c}$ & 2755 & 18.4 & 10.8 & 2572 & 1585 & $7.40 \mathrm{~b}$ & 7.95 & $53.6 \mathrm{~b}$ & 39.2 \\
\hline $\mathrm{CCC}_{\mathrm{R}}-\mathrm{C}-\mathrm{W}$ & $4637 \mathrm{ab}$ & 2890 & 19 & 10.01 & 2197 & 1485 & $6.18 \mathrm{f}$ & 8.11 & $47.6 \mathrm{~d}$ & 37.2 \\
\hline $\mathrm{CCC}_{\mathrm{SG}}-\mathrm{C}-\mathrm{W}$ & $3898 \mathrm{c}$ & 2419 & 18.6 & 10.63 & 2189 & 1260 & $6.55 \mathrm{e}$ & 7.82 & $51.3 \mathrm{c}$ & 38.2 \\
\hline $\mathrm{CV}, \%$ & 8.85 & 22.9 & 5.14 & 6.76 & 24.3 & 22 & 1.35 & 14.1 & 0.62 & 4.50 \\
\hline
\end{tabular}

${ }^{8} \mathrm{CV}$, coefficient of variation.

"Within a particular column, means followed by the same letter are not different according to LSD at $\mathrm{P}=0.05$.

$\ddagger$ NA, data not available.

\subsection{Plant Tissue}

In year 2, at site 1 , only canola plant tissue $\mathrm{P}, \mathrm{Ca}$, and $\mathrm{Zn}$ of the thirteen minerals $(\mathrm{N}, \mathrm{P}, \mathrm{K}, \mathrm{Ca}, \mathrm{Mg}, \mathrm{S}, \mathrm{Zn}, \mathrm{Mn}, \mathrm{Fe}$, $\mathrm{Cu}, \mathrm{B}, \mathrm{Al}, \mathrm{Na}$ ) were analyzed for here in the present study showed significant differences for the CTs investigated, while no canola plant tissue was impacted at site 2 (full data not presented). At site $1, \mathrm{~B}_{\mathrm{M}}-\mathrm{C}-\mathrm{W}$ had the highest plant tissue $\mathrm{P}$ and the lowest level of plant tissue $\mathrm{Zn}$ for canola. Marschner (2011) reported that increases in the levels of $\mathrm{P}$ in the plant tissue could lead to a decrease in $\mathrm{Zn}$ uptake. Both $\mathrm{CCC}_{\mathrm{F}}-\mathrm{C}-\mathrm{W}$ and $\mathrm{CCC}_{\mathrm{SG}^{-}} \mathrm{C}-\mathrm{W}$ had similar plant tissue Ca to P-C-W, but significantly higher than others. Going by the critical nutrient levels recommended by Holmes (1980) and Schwab et al. (2007) for annual crops, at site 1, canola tissue was deficient in $\mathrm{N}(<3.99 \% \mathrm{~N})$ for P-C-W, $\mathrm{CCC}_{\mathrm{F}}-\mathrm{C}-\mathrm{W}$ and $\mathrm{CCC}_{\mathrm{SG}}-\mathrm{C}-\mathrm{W}$. All CCC CTs in year 2 had insufficient $\mathrm{Cu}(<4 \mathrm{ppm})$. In general, all CTs were deficient in $\mathrm{B}(<29 \mathrm{ppm})$ and $\mathrm{K}(<2.79 \% \mathrm{~K})$. Other minerals measured here were mostly well within the critical nutrient levels for canola (year 2). For canola in year 2 at site 2 , nutrients in plant tissue were as follow: $\mathrm{Cu}$ was deficient in all $\mathrm{CTs}(<4 \mathrm{ppm} \mathrm{Cu}), \mathrm{B}$ was adequate only in P-C-W (control) and $\mathrm{CCC}_{\mathrm{G}}-\mathrm{C}-\mathrm{W}$, while $\mathrm{Na}$ was only deficient in $\mathrm{B}_{\mathrm{M}}-\mathrm{C}-\mathrm{W}(<0.11 \% \mathrm{Na})$.

In year 3, only wheat plant tissue $\mathrm{Ca}, \mathrm{Mg}$ and $\mathrm{Zn}$ differed for the $\mathrm{CT}$ (data not shown). $\mathrm{B}_{\mathrm{M}^{-}} \mathrm{C}-\mathrm{W}$ had the highest plant tissue P. P-C-W (control) had the highest K. Plant tissue $\mathrm{Ca}$ and $\mathrm{Zn}$ were higher for cropping treatments that had peas and CCC (regardless of the use of the CCC) in year 1 than both CTs that had barley seeded in year $1\left(\mathrm{~B}_{\mathrm{P}}-\mathrm{C}_{\mathrm{P}}-\mathrm{W}_{\mathrm{P}}\right.$ and $\left.\mathrm{B}_{\mathrm{M}}-\mathrm{C}-\mathrm{W}\right)$. The highest level of $\mathrm{Zn}$ uptake was done by the $\mathrm{CCC}_{\mathrm{G}}-\mathrm{C}-\mathrm{W}$ cropping system regardless of the crop (canola or wheat). This seems to suggest that peas or CCC might improve $\mathrm{Ca}$ and $\mathrm{Zn}$ availability for the benefit of subsequent crop production. This observation was also reflected in year 3 with wheat plant tissue (except for $\mathrm{Zn}$ with $\mathrm{B}_{\mathrm{P}}-\mathrm{C}_{\mathrm{P}}-\mathrm{W}_{\mathrm{P}}$ ). $\mathrm{CTs}$ did not impact plant tissue minerals at site 2 in year 3. In year 3, the wheat nutrient uptake was adequate for all $\mathrm{CTs}$ but deficient for $\mathrm{Cu}(<4 \mathrm{ppm})$ for P-C-W. It is important to note that the nutrient concentration that is considered adequate will change as the plant grows and matures.

\subsection{Soil Properties}

Soil nutrients were impacted by CT x year interaction effects at both sites. In the year following application, at site $1, \mathrm{~B}_{\mathrm{M}^{-}} \mathrm{C}-\mathrm{W}$ produced significantly higher soil $\mathrm{N}, \mathrm{P}, \mathrm{K}$ and $\mathrm{S}$ than others (Figures $1-4$ ). At site $2, \mathrm{~B}_{\mathrm{M}^{-}} \mathrm{C}-\mathrm{W}$ also produced the higher soil $\mathrm{N}$ (Figure 5), while $\mathrm{CCC}_{\mathrm{R}}-\mathrm{C}-\mathrm{W}$ had the most soil $\mathrm{P}$ and $\mathrm{K}$ (Figures 6 and 7). Except for $\mathrm{B}_{\mathrm{M}}-\mathrm{C}-\mathrm{W}$ and $\mathrm{CCC}_{\mathrm{R}}-\mathrm{C}-\mathrm{W}$ (in a few cases), in general, at both sites, soil $\mathrm{N}$ and $\mathrm{P}$ availability had a pattern of 
increasing their availability for year 2 but decreasing to below their initial levels of year 1 . The manure treatment $\left(\mathrm{B}_{\mathrm{M}}-\mathrm{C}-\mathrm{W}\right)$ in year 3 had soil $\mathrm{N}$ and $\mathrm{P}$ levels that were similar to year 1 . The generally higher soil $\mathrm{N}, \mathrm{P}, \mathrm{K}$, and $\mathrm{S}$ levels observed for all CTs in year 2, particularly for soil $\mathrm{N}$ and $\mathrm{P}$ seems to suggest that soil $\mathrm{N}$ and $\mathrm{P}$ credits were most apparent to the year following the implementation of CTs examined here (bio-stimulants, manure application, $\mathrm{CCC}$ for green manure, and grazing of $\mathrm{CCC}$ ) compared with the control crop rotation. At site 1, soil $\mathrm{K}$ availability was particularly influenced by the first year manure application treatment $\left(\mathrm{B}_{\mathrm{M}^{-}} \mathrm{C}-\mathrm{W}\right)$ which doubled its initial content (year 1) and remained remarkably similar for the following two years. It is important to state here that the inclusion or integration of CCC with grazing or when used for green manure reduced the amount of soil $\mathrm{N}$ and $\mathrm{P}$ depletion over the duration of this study at site 2 . This shows that crop-livestock integration or the use of CCC for green manure would greatly benefit the producers in terms of reduction in-organic fertilizer application over most of the other cropping systems. As stated earlier in this paper, strip grazing would have been ideal for maximizing the impact of both grazed CCCs and the residual soil $\mathrm{N}$ and $\mathrm{P}$ would have been much more significant than obtained in the present study. Future research studies aimed at planned strip grazing to investigate yearly fertility savings and cost: benefit ratio for subsequent crop production on a short and long-term basis are needed.

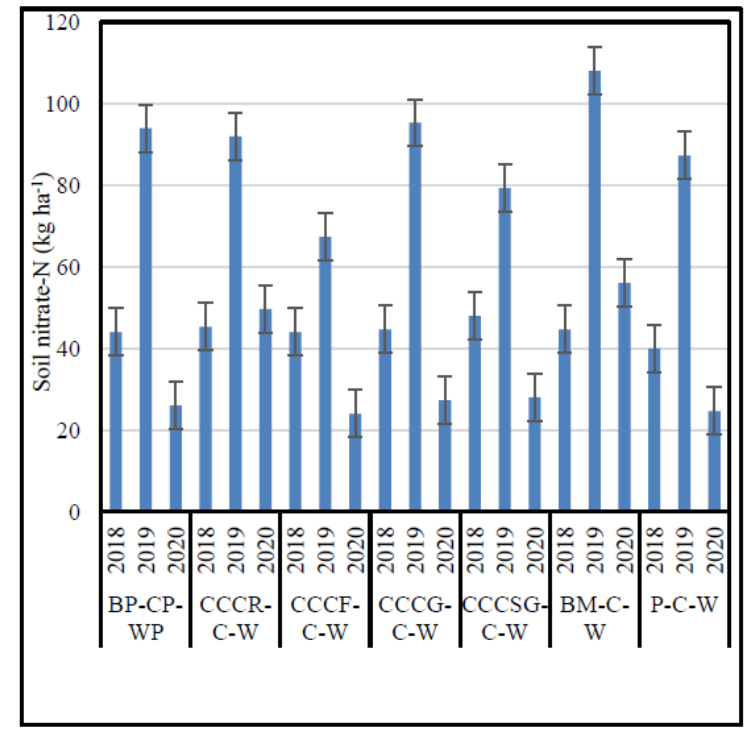

Figure 1. Soil nitrate-N for cropping treatments at site 1 for 3 years

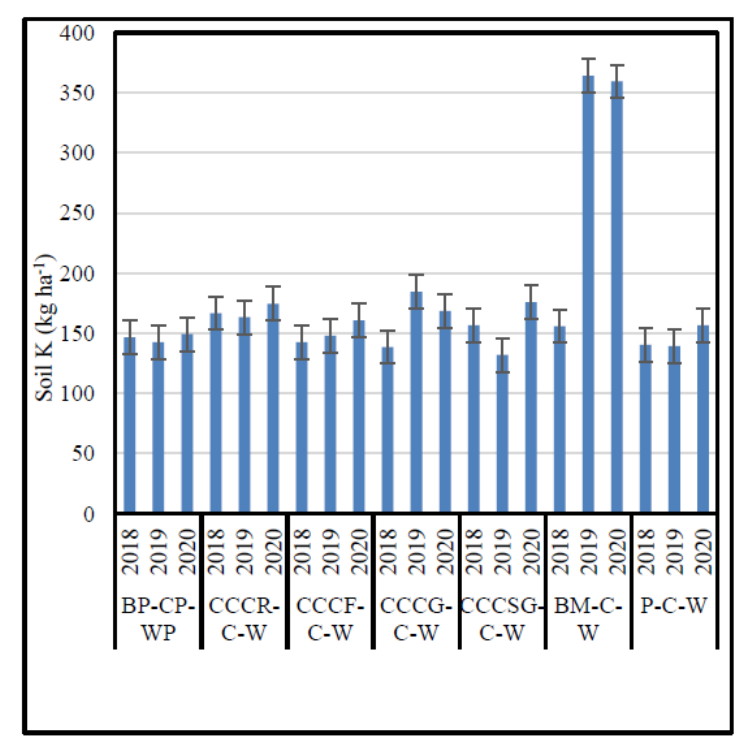

Figure 3. Soil K for cropping treatments at site 1 for 3 years

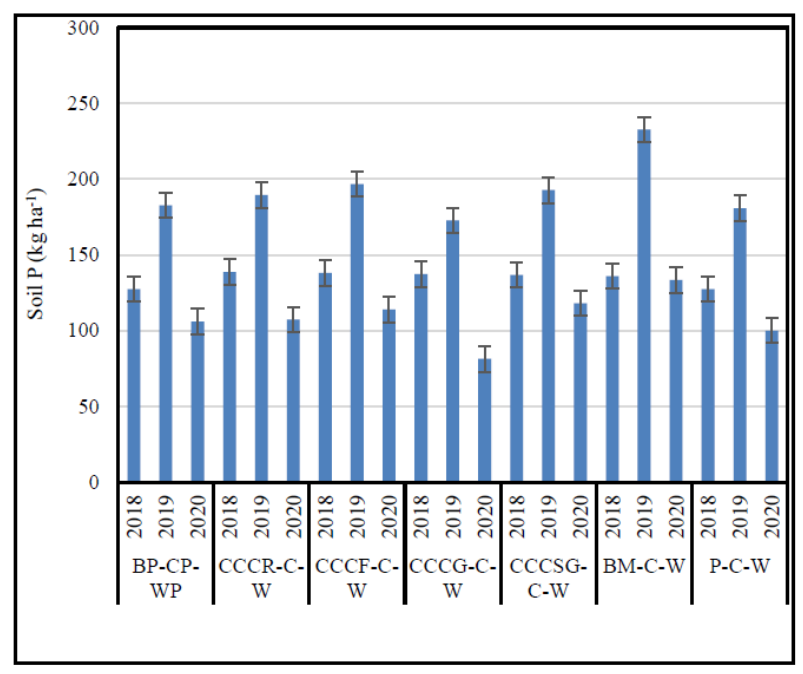

Figure 2. Soil $\mathrm{P}$ cropping treatments at site 1 for 3 years

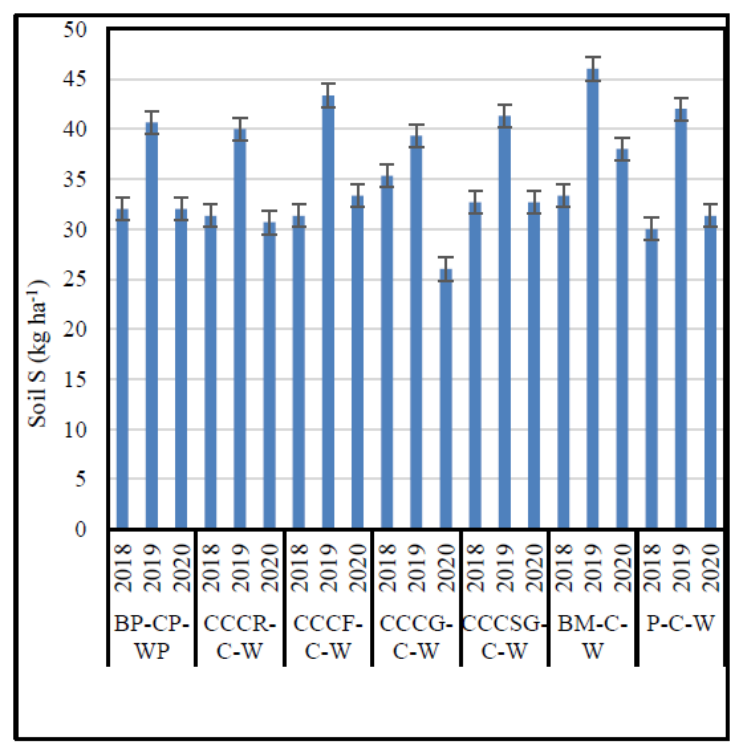

Figure 4. Soil S for cropping treatments at site 1 for 3 years 


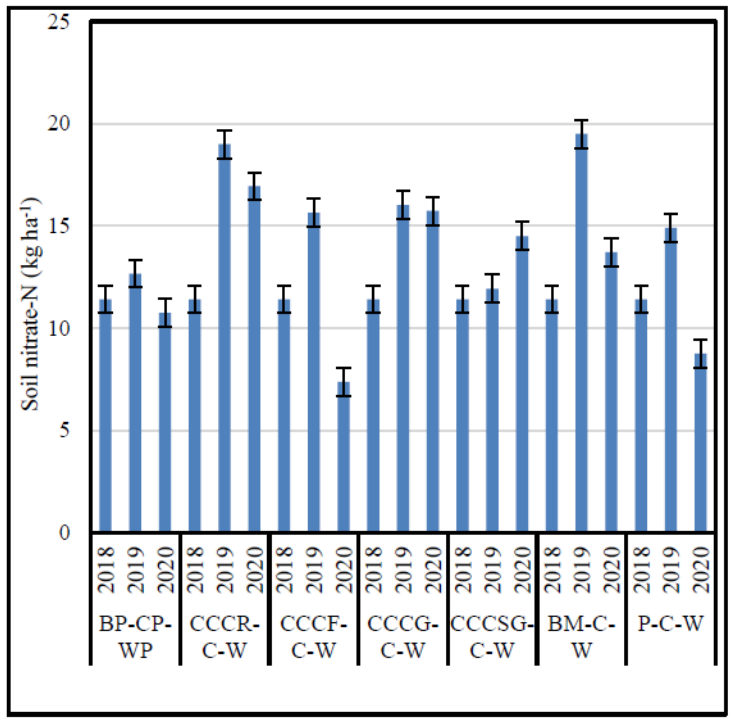

Figure 5. Soil nitrate- $\mathrm{N}$ for cropping treatments at site 2

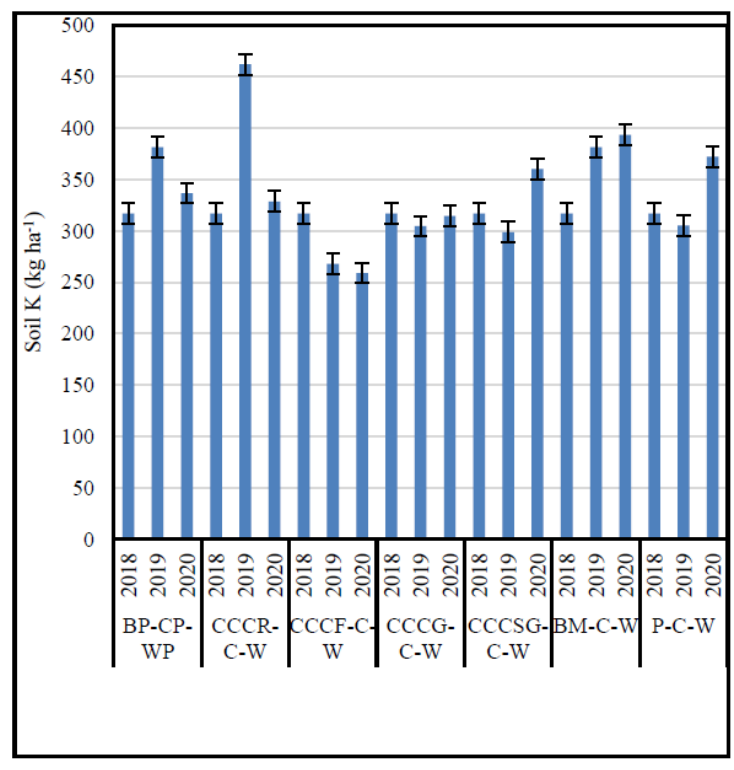

Figure 7. Soil K for CT cropping treatments at site 2 for 3 years

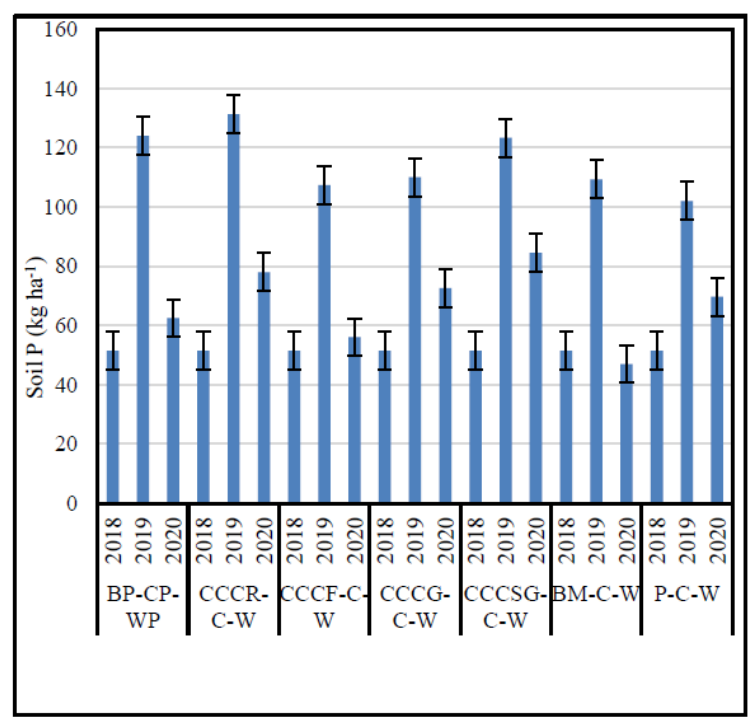

Figure 6. Soil $\mathrm{P}$ for cropping treatments at site 2 for 3.

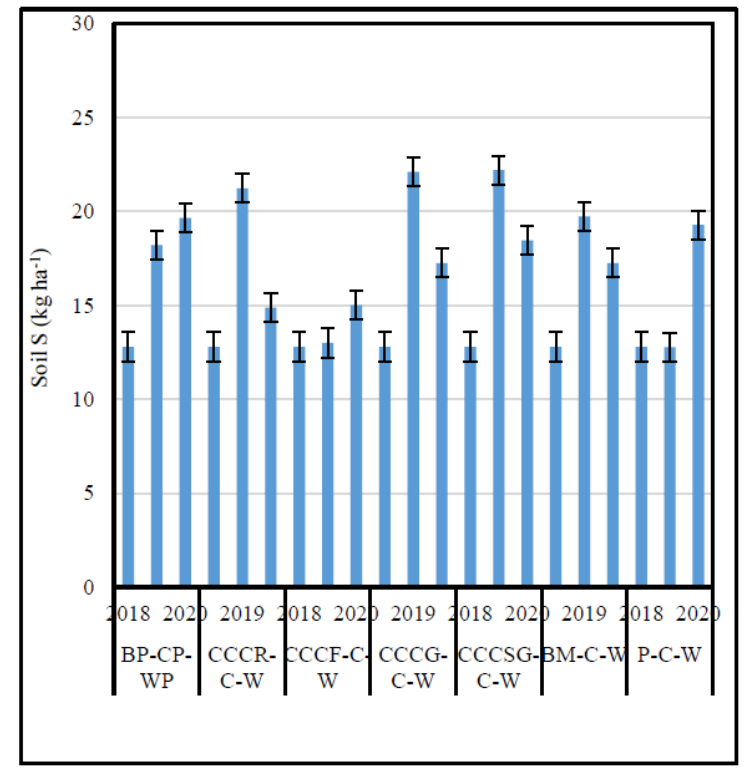

Figure 8. Soil $\mathrm{S}$ for cropping treatments at site 2 for 3 years

\subsection{Soil Quality Characteristics and Biological Activities}

$\mathrm{CT}$ was not significantly different for surface $\mathrm{SOM}$ and $\mathrm{pH}$, as well as all the following soil physical and biological activities: $\mathrm{BD}, \mathrm{SOC}, \mathrm{TN}$, and TC (data not shown).

For the SWAggr, AC, and SMResp, which were examined at two soil depths $(0-7.5$ and 7.5-15.0 cm), there were no significant CTs by soil depths interactions at both sites. The CTs did not have significant impacts on SWAggr, AC, and SMResp at each site. However, both AC and SMResp were influenced $(\mathrm{P}<0.05)$ by soil depths at both sites, but not SWAggr in any of the sites. As expected, AC and SMResp were consistently higher at 0-7.5 cm than 7.5-15.0 $\mathrm{cm}$ at both sites (Table 4). The higher AC in 0-7.5 $\mathrm{cm}$ at both sites indicates a trend toward more SOM building up in the soil through biological activity (Hoffland et al., 2020; Obalum et al., 2017). The higher SMResp in the 0-7.5 than 7.5-15.0 cm is an indication of presence of a larger, more active soil community (Hoffland et al., 2020). Surprisingly, SMResp values were similar for both sites at each examined soil depth. With the exception of SMResp, in general, all soil characteristics measured here were higher in values at site 1 
than site 2.

Table 4. Means of SWAggr, AC and SMResp for cropping treatments and soil depths for both sites 1 and 2

\begin{tabular}{|c|c|c|c|c|c|c|c|c|c|}
\hline \multirow{3}{*}{$\begin{array}{l}\text { Cropping } \\
\text { treatment }\end{array}$} & \multicolumn{8}{|c|}{ Site 1} & \multirow[b]{3}{*}{ mean } \\
\hline & \multicolumn{2}{|c|}{ SWAggr } & \multicolumn{3}{|c|}{$\mathrm{AC}$} & \multicolumn{3}{|c|}{ SMResp } & \\
\hline & $0-7.5 \mathrm{~cm}$ & $7.5-15 \mathrm{~cm}$ & Mean & $0-7.5 \mathrm{~cm}$ & $7.5-15 \mathrm{~cm}$ & mean & $0-7.5 \mathrm{~cm}$ & $7.5-15 \mathrm{~cm}$ & \\
\hline P-C-W (C) & 33.5 & 30.4 & $32.0 \mathrm{a}$ & 472 & 385 & $429 a$ & 0.72 & 0.48 & $0.60 \mathrm{a}$ \\
\hline $\mathrm{CCC}_{\mathrm{G}}-\mathrm{C}-\mathrm{W}$ & 29.9 & 27.8 & $28.9 \mathrm{a}$ & 445 & 370 & $408 \mathrm{a}$ & 0.7 & 0.51 & $0.61 \mathrm{a}$ \\
\hline $\mathrm{CCC}_{\mathrm{R}}-\mathrm{C}-\mathrm{W}$ & 27.1 & 28.3 & $27.7 \mathrm{a}$ & 482 & 335 & $409 \mathrm{a}$ & 0.72 & 0.44 & $0.58 \mathrm{a}$ \\
\hline BM-C-W & 29.3 & 24.5 & $26.9 \mathrm{a}$ & 456 & 332 & $394 a$ & 0.71 & 0.48 & $0.60 \mathrm{a}$ \\
\hline $\mathrm{CCC}_{\mathrm{SG}}-\mathrm{C}-\mathrm{W}$ & 27.1 & 30.5 & $28.8 \mathrm{a}$ & 461 & 343 & $402 \mathrm{a}$ & 0.74 & 0.48 & $0.61 \mathrm{a}$ \\
\hline $\mathrm{CCC}_{\mathrm{F}}-\mathrm{C}-\mathrm{W}$ & 28.6 & 31.2 & $29.9 \mathrm{a}$ & 410 & 315 & $363 a$ & 0.65 & 0.46 & $0.56 \mathrm{a}$ \\
\hline $\mathrm{B}_{\mathrm{P}}-\mathrm{C}_{\mathrm{P}}-\mathrm{W}_{\mathrm{P}}$ & 28.2 & 23.1 & $25.7 \mathrm{a}$ & 427 & 348 & $388 \mathrm{a}$ & 0.7 & 0.48 & $0.59 \mathrm{a}$ \\
\hline \multirow[t]{2}{*}{ Mean } & $29.1 \mathrm{a}$ & $28.0 \mathrm{a}$ & & $450 \mathrm{a}$ & $347 b$ & & $0.71 \mathrm{a}$ & $0.48 b$ & \\
\hline & \multicolumn{8}{|c|}{ Site 2} & \\
\hline \multirow{2}{*}{$\begin{array}{l}\text { Cropping } \\
\text { treatment }\end{array}$} & \multicolumn{2}{|c|}{ SWAggr } & & \multicolumn{2}{|c|}{$\mathrm{AC}$} & & \multicolumn{2}{|c|}{ SMResp } & \\
\hline & $0-7.5 \mathrm{~cm}$ & $7.5-15 \mathrm{~cm}$ & Mean & $0-7.5 \mathrm{~cm}$ & $7.5-15 \mathrm{~cm}$ & mean & $0-7.5 \mathrm{~cm}$ & $7.5-15 \mathrm{~cm}$ & mean \\
\hline P-C-W (C) & 23.8 & 21.2 & $22.5 \mathrm{a}$ & 259 & 235 & $247 a$ & 0.63 & 0.38 & $0.51 \mathrm{a}$ \\
\hline $\mathrm{CCC}_{\mathrm{G}}-\mathrm{C}-\mathrm{W}$ & 20 & 18.2 & $19.1 \mathrm{a}$ & 281 & 216 & $249 a$ & 0.74 & 0.48 & $0.61 \mathrm{a}$ \\
\hline $\mathrm{CCC}_{\mathrm{R}}-\mathrm{C}-\mathrm{W}$ & 24.6 & 24.3 & $24.5 \mathrm{a}$ & 279 & 176 & $228 \mathrm{a}$ & 0.72 & 0.48 & $0.60 \mathrm{a}$ \\
\hline BM-C-W & 22.2 & 22.9 & $22.6 \mathrm{a}$ & 232 & 147 & $190 \mathrm{a}$ & 0.67 & 0.68 & $0.68 \mathrm{a}$ \\
\hline $\mathrm{CCC}_{\mathrm{SG}}-\mathrm{C}-\mathrm{W}$ & 22 & 24.4 & $23.2 \mathrm{a}$ & 257 & 169 & $213 a$ & 0.74 & 0.51 & $0.63 \mathrm{a}$ \\
\hline $\mathrm{CCC}_{\mathrm{F}}-\mathrm{C}-\mathrm{W}$ & 22.8 & 22.3 & $22.6 \mathrm{a}$ & 214 & 149 & $182 \mathrm{a}$ & 0.8 & 0.64 & $0.72 \mathrm{a}$ \\
\hline $\mathrm{B}_{\mathrm{P}}-\mathrm{C}_{\mathrm{P}}-\mathrm{W}_{\mathrm{P}}$ & 21.1 & 28.6 & $24.9 \mathrm{a}$ & 223 & 171 & $197 \mathrm{a}$ & 0.6 & 0.44 & $0.52 \mathrm{a}$ \\
\hline Mean $^{\text {II }}$ & $22.4 \mathrm{a}$ & 23.1a & & $249 a$ & $180 \mathrm{~b}$ & & $0.70 \mathrm{a}$ & $0.51 b$ & \\
\hline
\end{tabular}

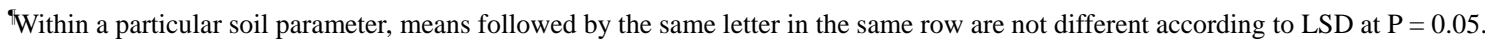

\section{Conclusion}

The evaluation of mixed crop-livestock systems during a 3-year period gave an indication of the potentiality of these systems to minimize the use of chemical fertilizer inputs for annual crops. Canola yields were significantly influenced by prior CTs at both sites. Three of the top yields over control (P-C-W) were for treatments: $\mathrm{B}_{\mathrm{M}^{-}} \mathrm{C}-\mathrm{W}$, $\mathrm{B}_{\mathrm{P}}-\mathrm{C}_{\mathrm{P}}-\mathrm{W}_{\mathrm{P}}$, and $\mathrm{CCC}_{\mathrm{R}}-\mathrm{C}-\mathrm{W}$. Canola straw $\mathrm{CP}$ and $\mathrm{TDN}$ can also be considered for utilization in these ecosystems. But their use will depend on what kind of livestock production is targeted. The effect of the first year was more pronounced on wheat grain yield at site 1 than site 2 . At site 1 , manure $\left(\mathrm{B}_{\mathrm{M}^{-}} \mathrm{C}-\mathrm{W}\right)$ produced high wheat grains, and was statistically similar to 2 of the $\mathrm{CCC}\left(\mathrm{CCC}_{\mathrm{G}}-\mathrm{C}-\mathrm{W}\right.$ and $\left.\mathrm{CCC}_{\mathrm{R}}-\mathrm{C}-\mathrm{W}\right)$. Wheat grain protein for the overall study was not influenced by the cropping system. Site 1 had a higher percentage of protein $(18.6 \%)$ than site 2 $(10.8 \%)$. Soil $\mathrm{P}$ levels at both sites for $\mathrm{B}_{\mathrm{M}^{-}} \mathrm{C}-\mathrm{W}$ had a higher level of soil $\mathrm{P}$ for year 2 . A crop-livestock integration or the use of $\mathrm{CCC}$ for green manure would have great benefit to producers in terms of savings in fertility cost for canola and wheat production over most of the other cropping systems. More studies need to be carried out to evaluate the appropriate cropping system to target specific constraints in the soil.

\section{Acknowledgments}

We would like to thank Peace Country Beef \& Forage Association summer crews and staff for their continued support throughout the project. This research was financially supported jointly Alberta Wheat Commission, Alberta Canola Producers Commission, and Alberta Agriculture and Forestry through the Agriculture Funding Consortium (Project Number 2018F146R).

\section{References}

A\&L Canada Laboratories Inc. (2019). 2019 A\&L Tissue sampling reference guide. A\&L Canada Laboratories Inc. pp. 26. Retrieved from www.alcanada.com

AAF (Alberta Agriculture \& Forestry). (2018). Using 1,000 Kernel Weight for Calculating Seeding Rates and Harvest Losses. Agri-Facts, Agdex 100/22-1.

AAF (Alberta Agriculture \& Forestry). (2019). 2019 Cropping alternatives. Retrieved from https://www.alberta.ca/cropping-alternatives.aspx

AAF (Alberta Agriculture \& Forestry). (2020). 2020 Cropping alternatives. Retrieved from https://www.alberta.ca/cropping-alternatives.aspx

AAF (Alberta Agriculture \& Forestry). (2020). 2021 Cropping alternatives. Retrieved from https://www.alberta.ca/cropping-alternatives.aspx 
ACIS (Alberta Climate Information Service ACIS). (2020). Current and historical Alberta weather station data viewer. Data provided by Alberta Agriculture and Forestry. Retrieved from https://acis.alberta.ca/acis/weather-data-viewer.jsp.

AOAC Official Method 972.43. (2006). Microchemical determination of carbon, hydrogen, and nitrogen, automated method. Off. Methods Anal. AOAC Int., 12, 5-6.

Barot, S., Allard, V., Cantarel, A., Enjalbert, J., Gauffreteau, A., Goldringer, I., ... Porcher, E. (2017). Designing mixtures of varieties for multifunctional agriculture with the help of ecology. A review. Agronomy for sustainable development, 37(2), 13. https://doi.org/10.1007/s13593-017-0418-x

Bell, L. W., \& Moore, A. D. (2012). Integrated crop-livestock systems in Australian agriculture: Trends, drivers and implications. Agricultural Systems, 111, 1-12. https://doi.org/10.1016/j.agsy.2012.04.003

Bonaudo, T., Bendahan, A. B., Sabatier, R., Ryschawy, J., Bellon, S., Leger, F., Magda, D., \& Tichit, M. (2014). Agroecological principles for the redesign of integrated crop-livestock systems. European Journal of Agronomy, 57, 43-51. https://doi.org/10.1016/j.eja.2013.09.010

CARA (Chinook Applied Research Association), (2016). Annual Reports.

Ciampitti, I. A., Garcia, F. O., Picone, L. I., \& Rubio, G. (2011). Soil C \& P pools in field crop rotations in Pampean soils of Argentina. Soil Sci. Soc. Am. J., 75, 616-625. https://doi.org/10.2136/sssaj2010.0168

CoStat Statistical Software. (2005). Cohort Version 6.2. Monterey, CA: Costat.

Garrett, R., Niles, M. T., Gil, J. D. B., Gaudin, A., Chaplin-Kramer, R., ... Assmann, A. (2017). Social and ecological analysis of integrated crop livestock systems: Current knowledge and remaining uncertainty. Agric Syst., 155, 136-46. https://doi.org/10.1016/j.agsy.2017.05.003

GOA (Government of Alberta). (2020). Alberta Soil Information Viewer. Retrieved from https://soil.agric.gov.ab.ca/agrasidviewer

GOWA (Government of Western Australia). (2021). Measuring and reporting soil organic carbon. Department of Primary Industries and Regional Development, Government of Western Australia. Retrieved from https://www.agric.wa.gov.au/soil-carbon/measuring-and-reporting-soil-organic-carbon

Hendrickson, J. R., Hanson, J. D., Tanaka, D. L., \& Sassenrath, G. (2008). Principles of integrated agricultural systems: Introduction to processes and definition. Renewable Agriculture and Food Systems, 23(4), 265-271. https://doi.org/10.1017/S1742170507001718

Hoffland, E., Kuyper, T. W., Comans, R. N., \& Creamer, R. E. (2020). Eco-functionality of organic matter in soils. Plant and Soil, 455, 1-22. https://doi.org/10.1007/s11104-020-04651-9

Holmes, M. R. J. (1980). Nutrition of the oilseed rape crop. Applied Science Publishers.

Ju, X., \& Christie, P. (2011). Calculation of theoretical nitrogen rate for simple nitrogen recommendations in intensive cropping systems: A case study on the North China Plain. Field Crops Research, 124(3), 450-458. https://doi.org/10.1016/j.fcr.2011.08.002

Lal, R. (2009). Soil C sequestration for climate change mitigation and food security. In Souvenir, Platinum Jubilee Symp. on Soil Science in Meet the Challenges to Food Security and Environmental Quality, New Delhi. Indian Soc. of Soil Sci., New Delhi. pp. 39-46.

Lemaire, G., Franzluebbers, A., Carvalho, P. C. de F., \& Dedieu, B. (2014). Integrated crop-livestock systems: Strategies to achieve synergy between agricultural production and environmental quality. Agriculture Ecosystem Environment, 190, 4-8. https://doi.org/10.1016/j.agee.2013.08.009

Marschner, H. (2011). Marschner's mineral nutrition of higher plants. Academic press.

Maynard, D., Kalra, Y., \& Crumbaugh, J. (2008). Nitrate and exchangeable ammonium nitrogen. In E. G. Gregorich \& M. R. Carter (Eds.), Soil sampling and methods of analysis (pp. 71-77). CRC Press, Boca Raton, FL.

Moraine, M., Grimaldi, J., Murgue, C., Duru, M., \& Therond, O. (2014). Integrating crop and livestock activities at territorial level in the watershed of Aveyron river: From current issues to collective innovative solutions. In Proceedings of 11th European IFSA Symposium, Berlin, Germany. pp. 1371-1384.

National Academies of Sciences, Engineering, and Medicine (NASEM). (2016). Nutrient requirements of beef cattle (8th ed.). The National Academies Press, Washington, DC. pp. 494. 
Obalum, S. E., Chibuike, G. U., Peth, S., \& Ouyang, Y. (2017). Soil organic matter as sole indicator of soil degradation. Environmental monitoring and assessment, 189(4), 176. https://doi.org/10.1007/s10661-017-5881-y

Omokanye, A. (2019). Cover crop cocktails for livestock feed. Presentation at Cocktail Cover Crop Workshop, Debolt Centre, Debolt, Alberta, Canada.

Peterson, C. A., Deiss, L., \& Gaudin, A. C. (2020). Commercial integrated crop-livestock systems achieve comparable crop yields to specialized production systems: A meta-analysis. PloS one, 15(5), e0231840. https://doi.org/10.1371/journal.pone.0231840

RStudio Team. (2021). RStudio: Integrated Development for R. RStudio, PBC, Boston, MA. Retrieved from http://www.rstudio.com

Russelle, M. P., Entz, M. H., \& Franzluebbers, A. J. (2007). Reconsidering integrated crop-livestock systems in North America. https://doi.org/10.2134/agronj2006.0139

Schindelbeck, R. R., Moebius-Clune, B. N., Moebius-Clune, D. J., Kurtz, K. S., \& van Es, H. M. (2016). Cornell University comprehensive assessment of soil health laboratory standard operating procedures. Ithaca, NY: Cornell University.

Schumacher, B. A. (2002). Methods for the determination of total organic carbon (TOC) in soils and sediments. NCEA-C-1282, EMASC-001. United States EPA, Las Vegas.

Schwab, G. J., Lee, C. D., \& Pearce, R. (2007). Sampling Plant tissue for Nutrient Analysis, University of Kentucky Cooperative Extension service.

Sparks, D. L., Page, A. L., Helmke, P. A., \& Loeppert, R. H. (Eds.). (2020). Methods of soil analysis, part 3: Chemical methods (Vol. 14). John Wiley \& Sons.

Yousaf, M., Li, X., Zhi Zhang, Z., Ren, T., Cong, R., Ata-Ul-Karim, S. T., Fahad, S., Shah, A. N., \& Lu, J. (2016). Nitrogen fertilizer management for enhancing crop productivity and nitrogen use efficiency in a rice-oilseed rape rotation system in China. Front Plant Sci., 7, 1496. https://doi.org/10.3389/fpls.2016.01496

\section{Copyrights}

Copyright for this article is retained by the author(s), with first publication rights granted to the journal.

This is an open-access article distributed under the terms and conditions of the Creative Commons Attribution license (http://creativecommons.org/licenses/by/3.0/). 